\title{
Identifying and assessing ecotourism visitor impacts at eight protected areas in Costa Rica and Belize
}

\author{
TRACY A. FARRELL ${ }^{1}$ AND JEFFREY L. MARION $2 *$ \\ ${ }^{1}$ School for Field Studies, 16 Broadway, Beverly, MA 01915, USA and ${ }^{2}$ USGS Patuxent Wildlife Research Center, Virginia Tech Cooperative \\ Park Studies Unit, 304 Cheatham Hall (0324), Blacksburg, Virginia 24061, USA
}

Date submitted: 1 December 2000 Date accepted: 30 May 2001

\section{Summary}

Protected area visitation is an important component of ecotourism, and as such, must be sustainable. However, protected area visitation may degrade natural resources, particularly in areas of concentrated visitor activities like trails and recreation sites. This is an important concern in ecotourism destinations such as Belize and Costa Rica, because they actively promote ecotourism and emphasize the pristine qualities of their natural resources. Research on visitor impacts to protected areas has many potential applications in protected area management, though it has not been widely applied in Central and South America. This study targeted this deficiency through manager interviews and evaluations of alternative impact assessment procedures at eight protected areas in Belize and Costa Rica. Impact assessment procedures included qualitative condition class systems, ratings systems, and measurement-based systems applied to trails and recreation sites. The resulting data characterize manager perceptions of impact problems, document trail and recreation site impacts, and provide examples of inexpensive, efficient and effective rapid impact assessment procedures. Interview subjects reported a variety of impacts affecting trails, recreation sites, wildlife, water, attraction features and other resources. Standardized assessment procedures were developed and applied to record trail and recreation site impacts. Impacts affecting the study areas included trail proliferation, erosion and widening, muddiness on trails, vegetation cover loss, soil and root exposure, and tree damage on recreation sites. The findings also illustrate the types of assessment data yielded by several alternative methods and demonstrate their utility to protected area managers. The need for additional rapid assessment procedures for wildlife, water, attraction feature and other resource impacts was also identified.

Keymords: visitor impacts, impact assessment, ecotourism, trail surveys, impact management, impact monitoring

\footnotetext{
* Correspondence: Dr Jeffrey L. Marion Tel: +1 5402316603 Fax: +1 5402313698 e-mail: jmarion@vt.edu
}

\section{Introduction}

Successful ecotourism and protected area management requires sustainable visitor use, necessitating the effective management of natural areas for visitor enjoyment and resource protection in perpetuity (WCED 1987). However, undesirable resource impacts related to tourism development and growth and protected area visitation have been documented in developed and developing countries (Hunter \& Green 1995; Mieczkowski 1995; Epler-Wood 1998). In particular, protected area visitation results in trail, recreation site, wildlife and water resource impacts, and degrades attractions like coral reefs (Liddle 1997; Marion \& Farrell 1998; Marion \& Leung 1998).

Visitor impacts have been identified as important management concerns by protected area managers in developing countries (Alderman 1990; Giongo et al. 1994). Trail and recreation site (e.g. campsite, picnic area, or attraction feature) impacts are of particular concern, because trailrelated recreation activities like hiking and wildlife viewing are popular visitor activities, and because trails and recreation sites often receive the most intensive visitor use within protected areas (Backman \& Potts 1993; Wight 1996).

Visitor impacts frequently occur at initial or low levels of use, and result in substantial resource changes in localized areas (Hammitt \& Cole 1998). Such impacts can decrease the functionality of facilities like trails and recreation sites, increase safety concerns, reduce aesthetic enjoyment and contribute to visitor displacement, create conflict between visitor groups, and increase management costs (Leung \& Marion 1996; Marion \& Farrell 1998).

Visitor impacts are especially relevant for protected areas in ecotourism destinations such as Belize and Costa Rica. Both countries have numerous protected areas comprising a substantial portion of their total area and are renowned for the undisturbed, pristine quality of their natural resources (Back \& Barry 1996). They also receive intensive visitation and emphasize natural resource protection over visitation in protected area legislation and mandates (P. Scott, Belize Audubon Society, Protected Areas Manager, Belize City, Belize, personal communication August 1998; R. Tenorio, Ministerio del Ambiente y Energia, Sistema Nacional de Areas de Conservacion, Area de Conservacion Cordillera Volcanica Central, Oficina de Investigaciones Cientificas, Director, San Jose, Costa Rica, personal communication 
August 1998). Therefore, research and management of visitor impacts is especially critical for protected areas in these countries.

To date, visitor impact research in protected areas in Costa Rica and Belize has been minimal. Boo (1990) listed visitor impacts affecting selected protected areas in both countries based on qualitative case study assessments. A few isolated studies of trail and wildlife impacts have also been conducted in Costa Rica (Boucher et al. 1991; Jacobsen \& Lopez 1994; Wallin \& Harden 1996).

Greater knowledge of the range of impacts affecting protected areas in Belize and Costa Rica would contribute to the larger discussion of ecotourism visitation impacts, identify areas of needed research and management, and aid in the development of impact monitoring programmes. Quantitative research is specifically needed for trails and recreation sites, because these types of settings are found in most protected areas and are locations of heavy visitor concentration.

In this paper, visitor impacts currently affecting natural resources at eight protected areas in Costa Rica and Belize are identified and described. Several types of impacts and impact assessment methods are applied to evaluate their applicability and utility to managers. Field evaluations and manager interviews are used to document visitor impacts, and demonstrate how rapid assessment procedures can quantify selected trail and recreation site impacts. The utility of alternative impact assessment procedures for protected area management is also considered.

\section{Study areas and methods}

\section{Study areas}

In August 1998, we investigated eight protected areas in Belize and Costa Rica, Central America. Belize is a small country $\left(22960 \mathrm{~km}^{2}\right.$ ) located between Mexico's south-eastern border and Guatemala. The country is predominantly lowland and includes $298 \mathrm{~km}$ of Caribbean coast (Mahler \& Wotkyns 1997). Costa Rica $\left(50984 \mathrm{~km}^{2}\right)$ is situated between Nicaragua and Panama. The country includes lowland and montane topography, as well as $212 \mathrm{~km}$ of Caribbean coast and $1022 \mathrm{~km}$ of Pacific coast (ICT-Costa Rica Tourist Board 1998).

The eight protected areas represented approximately 10\% of the protected areas in Costa Rica and 15\% of the protected areas in Belize. Study sites were selected to capture a variety of conditions potentially affecting the type, severity, assessment and management of visitor impacts. For example, protected areas with minimal visitation and limited access, visitor facility development and staff were expected to differ in visitor impacts from extensively developed, visited, managed and easily accessible areas. Therefore, the criteria evaluated to select a diversity of protected areas included intensity of development (infrastructure and visitor facilities), access (difficulty and regulation), management capacity (number of staff and funding), management agency (nongovernment organization, government or private), visitation (number of annual visitors), and environmental characteristics (marine, tropical or temperate; Table 1).

The sites selected have from one to fifteen permanent staff and offer limited to extensive visitor facilities and services (e.g. guiding services, visitor centres, lodges, bathroom facilities and reinforced trails). They range in size from 1036 to 71212 ha, providing protection for a variety of ecosystems and topographic features including lowland and upland tropical rain forests, volcanic craters, and coral reefs. Annual visitation ranges from 3000 visitors at the Community Baboon Sanctuary, Belize, to 215930 visitors at Volcan Poas National Park, Costa Rica. Visitor activities include sightseeing, hiking, viewing wildlife, exploring archaeological ruins, boat tours, sunbathing, swimming, snorkelling, and diving. Primary attractions include coral reefs, archaeological ruins, rain forests, wildlife, and beaches. Both government and non-government organizations (NGOs) are responsible for protected area management (Table 1).

\section{Methods}

Research methods included interviews to identify the types of visitor impacts considered important by managers and condition assessments to measure trail and site impacts. These methods were applied at study areas during site visits lasting 1-2 days in August 1998.

\section{Manager interviems}

Ten semi-structured interviews were conducted with protected area managers and managing agency representatives who were selected from contact lists provided by The Ecotourism Society, Conservation International and The Nature Conservancy. Interview subjects were selected based on their expertise and knowledge about visitor impact management issues for a given protected area. Interviews were pre-arranged when possible and were conducted in English or Spanish, depending on the native language of the interview subject. Interview data were tape recorded and later summarized.

Questions addressed visitor activities and visitation, potential underlying causes of impacts, and constraints to impact monitoring and management. Interview subjects were asked about visitor impacts currently affecting their protected areas to identify impacts of particular management concern. Subjects also identified and described visitor impacts from a prepared list containing 43 items in eight impact categories: trails, roads, campsites, recreation sites, wildlife, water, litter/fecal matter, and inappropriate visitor behaviours. This listing was included to ensure a comprehensive documentation of visitor impacts.

\section{Trail and recreation site selection}

Protected areas selected generally had few trails and recreation sites, with even fewer trails and recreation sites 
Table 1 Attributes and characteristics of protected areas selected for case studies in Costa Rica (CR) and Belize (BE). Information was derived from interviews and available protected area studies.

\begin{tabular}{|c|c|c|c|c|c|c|}
\hline $\begin{array}{l}\text { Protected area } \\
\text { name and location }\end{array}$ & $\begin{array}{l}\text { Size } \\
\text { (ha) }\end{array}$ & $\begin{array}{l}\text { Number of } \\
\text { visitors per } \\
\text { annum }\end{array}$ & $\begin{array}{l}\text { Development/ } \\
\text { management }\end{array}$ & $\begin{array}{l}\text { Primary } \\
\text { visitor } \\
\text { activities }\end{array}$ & $\begin{array}{l}\text { Managing } \\
\text { agency }\end{array}$ & $\begin{array}{l}\text { Primary } \\
\text { attractions }\end{array}$ \\
\hline $\begin{array}{l}\text { Braulio Carrillo National } \\
\text { Park, CR, } 20 \mathrm{~km} \text { NE of } \\
\text { San José }\end{array}$ & 46000 & 13801 & $\begin{array}{l}\text { Few facilities/ } \\
\quad<5 \text { staff }\end{array}$ & $\begin{array}{l}\text { Sightseeing, } \\
\text { hiking, wildlife } \\
\text { viewing }\end{array}$ & $\begin{array}{l}\text { National Park } \\
\text { Service }\end{array}$ & $\begin{array}{l}\text { Rain forests, } \\
\text { mountains, } \\
\text { wildlife }\end{array}$ \\
\hline $\begin{array}{l}\text { Community Baboon } \\
\text { Sanctuary, BE, } 48 \mathrm{~km} \\
\text { NW of BE City }\end{array}$ & 5180 & 3000 & $\begin{array}{l}\text { Few facilities/ } \\
\quad<5 \text { staff }\end{array}$ & $\begin{array}{l}\text { Wildlife } \\
\text { viewing, hiking }\end{array}$ & Local NGO & $\begin{array}{c}\text { Black howler } \\
\text { monkeys }\end{array}$ \\
\hline $\begin{array}{l}\text { Altun } \mathrm{Ha}, \mathrm{BE}, 50 \mathrm{~km} \\
\mathrm{~N} \text { of BE City }\end{array}$ & 1036 & 15000 & $\begin{array}{l}\text { Moderate facilities/ } \\
\quad<5 \text { staff }\end{array}$ & Exploring ruins & $\begin{array}{r}\text { Department of } \\
\text { Archaeology }\end{array}$ & Mayan ruins \\
\hline $\begin{array}{l}\text { Hol Chan Marine } \\
\text { Reserve, BE, } 40 \mathrm{~km} \\
\text { NE of BE City }\end{array}$ & 1295 & 40000 & $\begin{array}{l}\text { Moderate facilities/ } \\
\quad<10 \text { staff }\end{array}$ & $\begin{array}{l}\text { Snorkelling, } \\
\text { diving }\end{array}$ & $\begin{array}{l}\text { Minister of } \\
\text { Agriculture \& } \\
\text { Fisheries }\end{array}$ & $\begin{array}{l}\text { Coral reefs, } \\
\text { marine life }\end{array}$ \\
\hline $\begin{array}{l}\text { Tortuguero National } \\
\text { Park, CR, } 400 \mathrm{~km} \mathrm{NW} \\
\text { of San José }\end{array}$ & 71212 & 18946 & $\begin{array}{l}\text { Moderate facilities/ } \\
\quad<10 \text { staff }\end{array}$ & $\begin{array}{l}\text { Wildlife } \\
\text { viewing, boat } \\
\text { tours }\end{array}$ & $\begin{array}{l}\text { National Park } \\
\text { Service }\end{array}$ & $\begin{array}{l}\text { Sea turtles, } \\
\quad \text { estuaries, wildlife }\end{array}$ \\
\hline $\begin{array}{l}\text { Manuel Antonio National } \\
\text { Park, CR, } 275 \mathrm{~km} \\
\text { S of San José }\end{array}$ & 55682 & 114922 & $\begin{array}{l}\text { Extensive facilities/ } \\
\quad<20 \text { staff }\end{array}$ & $\begin{array}{l}\text { Sunbathing, } \\
\text { hiking, wildlife } \\
\text { viewing }\end{array}$ & $\begin{array}{l}\text { National Park } \\
\text { Service }\end{array}$ & $\begin{array}{l}\text { Beaches, forests, } \\
\text { wildlife }\end{array}$ \\
\hline $\begin{array}{l}\text { Monteverde Cloud Forest } \\
\text { Reserve, CR, } 160 \mathrm{~km} \\
\text { NW of San José }\end{array}$ & 10522 & 50000 & $\begin{array}{l}\text { Extensive facilities/ } \\
\quad<20 \text { staff }\end{array}$ & $\begin{array}{l}\text { Wildlife } \\
\text { viewing, hiking, } \\
\text { sightseeing }\end{array}$ & Research NGO & $\begin{array}{l}\text { Cloud forests, } \\
\text { wildlife }\end{array}$ \\
\hline $\begin{array}{l}\text { Volcan Poas National } \\
\text { Park, CR, } 55 \mathrm{~km} \mathrm{NW} \\
\text { of San José }\end{array}$ & 5600 & 215930 & $\begin{array}{l}\text { Extensive facilities/ } \\
\quad<20 \text { staff }\end{array}$ & $\begin{array}{l}\text { Viewing } \\
\text { volcanic craters, } \\
\text { hiking }\end{array}$ & $\begin{array}{l}\text { National Park } \\
\text { Service }\end{array}$ & $\begin{array}{l}\text { Volcanic craters, } \\
\text { dwarf cloud forest }\end{array}$ \\
\hline
\end{tabular}

experiencing significant visitor use. Therefore, we purposively selected and assessed the most heavily visited trails and/or recreation sites within each protected area, based on input from protected area staff. The rationale for purposive sampling was to maintain consistency between protected areas, and to ensure that at least some visitor-related impacts would be found so that trail and recreation site assessment methods could be applied and adequately evaluated. Exclusion of lesser-used facilities does bias study findings towards greater impact.

We assessed two of the four picnic areas at Manuel Antonio National Park, Costa Rica, one of the two plazas at Altun $\mathrm{Ha}$, Belize, and one of the two volcanic crater viewing areas at Volcan Poas National Park, Costa Rica, capturing half of all of the recreation sites at each protected area.

A single trail was surveyed at protected areas with less than three trails (Volcan Poas National Park, and Braulio Carrillo National Park, Costa Rica, and the Community Baboon Sanctuary, Belize), and two trails were surveyed at protected areas with up to eight trails (Monteverde Cloud Forest Reserve and Manuel Antonio National Park, Costa Rica). A total of $5.9 \mathrm{~km}$ of trails were measured, ranging from $0.5 \mathrm{~km}$ to $1.7 \mathrm{~km}$ in length. Remaining unselected trails were under construction, used as travel routes only for local residents, or experienced minimal visitor use.

\section{Trail and recreation site impact assessment methods}

Multiple procedures for assessing visitor impacts to trails and recreation sites were developed to generate different types of information and compare assessment methods. The need for objective and efficient standardized methods suitable for use in monitoring programmes guided the development of specific procedures employed in this study. Assessment techniques were selected to maximize accuracy, precision, and sensitivity, to be cost efficient, and to yield information of high relevance to managers.

Trail assessment procedures. We used multiple trail assessment methods to: (1) characterize overall trail conditions, (2) determine the frequency, lineal extent and location of selected tread problems, and (3) document trail design and maintenance features. These methods included condition class ratings (ordinal data) and measurement-based methods (ratio data).

Condition class ratings were assigned to each trail to characterize the general condition of the entire trail based on 
visual assessments of disturbance to vegetation, organic litter, and soils. We also estimated the total length, assessed condition class and recorded erosion ratings for trails ascending the steep slopes of Altun Ha's ruin buildings. Ratings ranged from $0-5$, with 0 representing minimal disturbance and 5 representing complete vegetation and organic litter loss and extensive soil erosion.

Measurement-based trail assessment methods included both point sampling and problem assessment approaches. The point sampling method characterizes trail conditions through quantitative measures of impact indicators taken at a systematic interval along a trail segment (Cole 1983; Leung \& Marion 1999a). Sample points were located every $70 \mathrm{~m}$ by pushing a measuring wheel $(122 \mathrm{~cm}$ circumference) along each surveyed trail. Measurements were taken along transects oriented perpendicular to the trail at each sample point.

Trail impact indicators included tread width (width of tread that is devoid of vegetation), tread incision (maximum post-construction incision depth of tread surface), visitorcreated trails (number of trails created by visitors to cut switchbacks or access attraction features recorded between each sampling point), and a visual estimate of the tread composition (percentage bare soil, organic litter, vegetation, gravel, cement/lattice blocks, and wood planking).

We collected condition class and point sampling data from seven trails in five protected areas. The remaining protected areas either did not have trails or trails were used almost exclusively by local people (Hol Chan Marine Reserve and Altun Ha, Belize, and Tortuguero National Park, Costa Rica). For the purposes of this study we wanted to be able to distinguish visitor impacts from local use impacts. Data were gathered from nine to 28 sampling points per trail, depending on the total trail length (from $549 \mathrm{~m}$ to $1767 \mathrm{~m}$ ).

Summary statistics were computed for trail incision (an indicator of soil erosion) and trail width. Measures of central tendency (median and mean), standard deviation, minimum and maximum values are reported. Mean values are presented for normally distributed data, based on ShapiroWilks tests $(\alpha=0.05)$.

A problem assessment method (Leung \& Marion 1999b) was also applied to five of the trails assessed with point sampling to document the number, location, and lineal extent of six predefined trail impact indicators. Using a measuring wheel, distances from the trailhead to the beginning and end of each occurrence of the impact indicators were recorded for occurrences extending at least three metres. Indicators included wet soil (wet, muddy soil or standing water on more than half the tread width), running water on trail (moving water present on the tread), multiple treads (two or more parallel treads), excessive width (expansion of tread width two or more metres greater than adjacent sections), excessive erosion (post-construction tread incision of more than $15 \mathrm{~cm}$ to capture post-construction erosion) and root exposure (tops and sides of many tree roots exposed). Additional information on these trail impact assessment and monitoring methods may be found in Cole (1983), Leung and Marion (1996), and Leung et al. (1997).

The accuracy and precision of determining the start and end points for problem assessment indicators were improved by using detailed descriptive procedures, colour photographs, and staff training (Leung \& Marion 1999b). We also periodically examined reliability between the two investigators by comparing our starting and ending points, further refining procedures where necessary.

Recreation site assessment procedures. We used multiple assessment methods to: (1) inventory recreation site features, (2) characterize overall recreation site conditions, and (3) document conditions for selected recreation site impact indicators. These methods included condition class and categorical ratings (ordinal data), and measurement-based procedures (ratio data). A multi-indicator measurement-based system was also applied to provide more specific documentation of different types of impacts.

Recreation site measurements follow procedures described in Marion (1991). Six site impact indicators were assessed, namely site size, vegetation cover loss, exposed soil, visitor-caused tree damage, tree root exposure, and litter (percentage of a 151 refuse bag filled). One inventory indicator was documented, namely site surfacing (vegetation, soil, bed rock, and paved/gravelled), where each surface type was visually assessed as a percentage of the entire site.

Recreation site size was determined by measuring the dimensions of one or more geometric figures superimposed to closely match site boundaries (Marion 1991). Vegetation cover loss and mineral soil exposure due to human trampling were estimated by subtracting mid-point values of $20 \%$ cover classes assessed on-site and in adjacent undisturbed control sites. Additional information on these recreation site assessment procedures may be found in Cole (1989) and Marion (1991, 1995).

\section{Results}

\section{Interview information: visitor impacts}

Interview information revealed a variety of trail, recreation site, attraction feature, wildlife, water, and other impacts affecting the study areas. Trail and recreation site impacts were particularly important management concerns. The most commonly reported trail impacts were excessive erosion, exposed roots, muddy soil and visitor-created trails. The most prevalent recreation site impacts included exposed soil, vegetation cover loss, and damaged trees.

Attraction feature and facility impacts were also identified, such as erosion of Altun Ha's stone ruin structures, erosion of soil surrounding tiered benches at a volcanic crater viewing area in Volcan Poas, and coral damage at Hol Chan (e.g. broken coral structures).

Interview subjects also identified wildlife impacts, including feeding and subsequent attraction/nuisance 
behaviour, and wildlife disturbance and harassment. Other concerns included water impacts, such as oil and gas pollution, biological contamination, litter, illegal hunting and fishing, collecting plants and animals, vandalism, and graffiti. For example, guides at the Community Baboon Sanctuary fed black howler monkeys and induced their calling, tour boat operation contributed to oil and gas pollution at $\mathrm{Hol}$ Chan, Tortuguero and Manuel Antonio, and tourists at Volcan Poas commonly broke off large leaves from umbrella plants for rain protection.

Trail and recreation site condition assessments measured similar impacts reported by study site managers, with the exception of Volcan Poas, where interview information revealed that we might not have captured many previously common trail and site impacts due to recent trail and site development efforts.

Trail impacts: condition class and point sampling methods

The condition class ratings ranged from 3.0 (Crater trail, Volcan Poas National Park) to 4.5 (Las Palmas trail, Braulio
Carrulo National Park), the latter experiencing a complete loss of vegetation cover and organic litter with areas of obvious soil erosion and exposed roots (Table 2). Three trails were extensively shielded by trail surfacing, paving or other construction materials like embedded cement lattice blocks that prevented application of the condition class ratings (Table 2).

The trail treads of the Las Palmas, Bremudian Landing and Entrance trails were primarily composed of bare soil while the Crater trail was surfaced exclusively by gravel (Table 2). The Bosque Eterno and Rio Chomorgo trails were surfaced with a mixture of cement lattice blocks, wood planking and gravel. Rot-resistant wood planking and sawed tree cross-sections were commonly used on the Las Palmas trail.

Trail width ranged from narrow $(26 \mathrm{~cm})$ to exceptionally wide $(386 \mathrm{~cm})$, though some trails were constructed with greater widths to accommodate larger numbers of visitors. Nature trails, such as Las Palmas, Puerto Escondito and Rio Chomorgo, had the smallest mean widths (under $100 \mathrm{~cm}$ ). Trail erosion, as indicated by tread incision, was most significant on poorly designed and constructed trails, such as the

Table 2 Summary of trail condition class and point sampling results for case study protected areas in Costa Rica and Belize. $\mathrm{SD}=$ standard deviation, $\mathrm{NA}=$ not available,$-=$ no data, $\mathrm{n}=$ sample size.

\begin{tabular}{|c|c|c|c|c|c|c|c|}
\hline \multirow{3}{*}{$\begin{array}{l}\text { Impact } \\
\text { indicators }\end{array}$} & \multicolumn{7}{|c|}{ Protected areas and locations affected } \\
\hline & \multirow{2}{*}{$\begin{array}{l}\text { Braulio } \\
\text { Carrillo } \\
\text { National } \\
\text { Park } \\
\text { Las Palmas } \\
\text { trail } \\
(1767 \mathrm{~m})\end{array}$} & \multirow{2}{*}{$\begin{array}{l}\text { Community } \\
\text { Baboon } \\
\text { Sanctuary } \\
\\
\text { Bremudian } \\
\text { Landing } \\
\text { trail } \\
(564 \mathrm{~m})\end{array}$} & \multicolumn{2}{|c|}{$\begin{array}{l}\text { Manuel Antonio National } \\
\text { Park }\end{array}$} & \multicolumn{2}{|c|}{$\begin{array}{l}\text { Monteverde Cloud Forest } \\
\text { Reserve }\end{array}$} & \multirow{2}{*}{$\begin{array}{l}\text { Volcan Poas } \\
\text { National } \\
\text { Park } \\
\text { Crater trail } \\
(620 \mathrm{~m})\end{array}$} \\
\hline & & & $\begin{array}{l}\text { Entrance } \\
\text { trail } \\
(861 \mathrm{~m})\end{array}$ & $\begin{array}{l}\text { Puerto } \\
\text { Escondito } \\
\text { trail } \\
(946 \mathrm{~m})\end{array}$ & $\begin{array}{l}\text { Bosque } \\
\text { Eterno } \\
\text { trail } \\
(549 \mathrm{~m})\end{array}$ & $\begin{array}{l}\text { Rio } \\
\text { Chomorgo } \\
\text { trail } \\
(615 \mathrm{~m})\end{array}$ & \\
\hline \multicolumn{8}{|l|}{ Condition class } \\
\hline \multicolumn{8}{|l|}{ Composition (\%) } \\
\hline Bare soil & 40.6 & 55.6 & 90.0 & 10.7 & - & - & 0 \\
\hline Litter & 14.3 & 21.7 & 10.0 & 5.3 & - & - & 0 \\
\hline Vegetation & 0 & 22.8 & 0 & 0 & - & - & 0 \\
\hline Gravel & 3.7 & 0 & 0 & 20.7 & - & - & 100 \\
\hline Cement/lattice & 7.4 & 0 & 0 & 63.3 & - & - & 0 \\
\hline Wood planking & 35.6 & 0 & 0 & 0 & - & - & 0 \\
\hline \multicolumn{8}{|l|}{ Width (cm) } \\
\hline Mean (SD) & $71.9(21.6)$ & $126.2(41.7)$ & $252.3(68.7)$ & $87.7(43.1)$ & $127.0(37.5)$ & $91.7(19.7)$ & $157.2(7.6)$ \\
\hline Range & $26-117$ & $81-213$ & $152-386$ & $58-198$ & $84-188$ & $84-147$ & $150-175$ \\
\hline $\mathrm{n}$ & 28 & 9 & 12 & 15 & 9 & 10 & 10 \\
\hline \multicolumn{8}{|l|}{ Incision (cm) } \\
\hline Median & 4.5 & 5.1 & 3.8 & 0 & 0 & 0 & 0 \\
\hline Min-Max & $0-25$ & $0-13$ & $0-18$ & $0-38$ & 0 & $0-13$ & 0 \\
\hline $\mathrm{n}$ & 28 & 9 & 12 & 15 & 9 & 10 & 10 \\
\hline $\begin{array}{l}\text { Visitor-created } \\
\text { trails (number } \\
\text { per sampling } \\
\text { point) }\end{array}$ & 2 & 0 & 11 & 4 & 0 & 0 & 0 \\
\hline
\end{tabular}


Bremudian Landing trail $(5.1 \mathrm{~cm})$ and the Las Palmas trail $(4.5 \mathrm{~cm})$. Erosion was not present on trails with improved design and artificial surfacing.

Problems with trail proliferation were relatively common. Eleven visitor-created trails branched off of the Entrance trail and another four originated from the Puerto Escondito trail at Manuel Antonio. Six trails were found on the steep sides of three Altun Ha ruin structures, ranging from $15-30 \mathrm{~m}$ in length.

\section{Trail impacts: problem assessment method}

Excessive soil erosion was most prevalent on the Las Palmas trail, with 25 recorded instances affecting $241 \mathrm{~m}$ (14\%) of the trail (Table 3). Root exposure also was common, with 12 occurrences affecting $18 \%$ of the trail. In contrast, Bremudian Landing experienced only three instances of excessive erosion, and the remaining trails were unaffected. Bosque Eterno had one extremely long segment of exposed roots, extending $69 \mathrm{~m}$ (13\% of the total trail length). Muddy soil was recorded at nine locations on Las Palmas, for a total lineal extent of $40 \mathrm{~m}$. In spite of high tropical rainfall no instances of muddy soil were recorded for the other trails. Ten excessively wide segments $(>2 \mathrm{~m})$ were measured at Bosque Eterno, affecting $24 \%$ of the total trail length.
Multiple trailing and running water on trails were uncommon problems.

\section{Recreation site impacts}

Four recreation sites were surveyed in three protected areas using condition class and multi-indicator impact assessment approaches (Table 4). The Manuel Antonio picnic sites received a condition class rating of 4, defined as nearly complete or total loss of vegetation cover and organic litter, with widespread bare soil (Table 4). In contrast, the vegetated ruin plaza in Altun Ha was rated a 1, where only a slight loss of vegetation cover and/or minimal disturbance of organic litter occurred. A condition class rating could not be applied to the crater-viewing site at Volcan Poas due to the extensive use of gravel to harden the natural substrate.

Recreation site size ranged from Manuel Antonio's relatively small picnic areas $\left(717 \mathrm{~m}^{2}\right.$ and $\left.812 \mathrm{~m}^{2}\right)$ to Altun Ha's extremely large grassy plaza (283 ha; Table 4$)$. The picnic areas at Manuel Antonio experienced the most vegetation cover loss (91\%) and the most exposed soil (71\%). Conversely, only $10 \%$ vegetation cover loss and exposed soil occurred at Altun Ha's ruin plaza. Evidence of soil disturbance and compaction, and three damaged trees also were recorded for the Manual Antonio sites.

Table 3 Trail problem assessment results for case study protected areas in Costa Rica and Belize. $\mathrm{n}=$ number of occurrences.

\begin{tabular}{|c|c|c|c|c|c|}
\hline \multirow{3}{*}{$\begin{array}{l}\text { Impact } \\
\text { indicators }\end{array}$} & \multicolumn{5}{|c|}{ Protected areas and locations affected } \\
\hline & \multirow{2}{*}{$\begin{array}{l}\text { Braulio } \\
\text { Carrillo } \\
\text { National Park } \\
\text { Las Palmas } \\
\text { trail } \\
(1767 \mathrm{~m}) \\
\end{array}$} & \multirow{2}{*}{$\begin{array}{l}\text { Community } \\
\text { Baboon } \\
\text { Sanctuary } \\
\text { Bremudian } \\
\text { Landing trail } \\
(564 \mathrm{~m}) \\
\end{array}$} & \multicolumn{2}{|c|}{$\begin{array}{l}\text { Monteverde Cloud Forest } \\
\text { Reserve }\end{array}$} & \multirow{2}{*}{$\begin{array}{l}\text { Volcan Poas } \\
\text { National Park } \\
\text { Crater } \\
\text { trail } \\
(620 \mathrm{~m}) \\
\end{array}$} \\
\hline & & & $\begin{array}{l}\text { Bosque } \\
\text { Eterno trail } \\
(549 \mathrm{~m})\end{array}$ & $\begin{array}{l}\text { Rio } \\
\text { Chomorgo trail } \\
(615 \mathrm{~m})\end{array}$ & \\
\hline \multicolumn{6}{|l|}{$\begin{array}{l}\text { Excessive erosion } \\
(>15 \mathrm{~cm})\end{array}$} \\
\hline Occurrences (n) & 25 & 3 & 0 & 0 & 0 \\
\hline Lineal distance $(\mathrm{m})$ & 241 & 13 & 0 & 0 & 0 \\
\hline \multicolumn{6}{|l|}{ Exposed roots } \\
\hline Occurrences (n) & 12 & 1 & 1 & 1 & 0 \\
\hline Lineal distance $(\mathrm{m})$ & 318 & 5 & 69 & 7 & 0 \\
\hline \multicolumn{6}{|l|}{ Multiple trails } \\
\hline Occurrences (n) & 1 & 2 & 0 & 0 & 0 \\
\hline Lineal distance $(\mathrm{m})$ & 8 & 12 & 0 & 0 & 0 \\
\hline \multicolumn{6}{|l|}{ Muddy soil } \\
\hline Occurrences (n) & 9 & 0 & 0 & 0 & 0 \\
\hline Lineal distance (m) & 40 & 0 & 0 & 0 & 0 \\
\hline \multicolumn{6}{|l|}{ Excessive width } \\
\hline \multicolumn{6}{|l|}{ (>2 $m$ midth increase) } \\
\hline Occurrences (n) & 0 & 2 & 10 & 2 & 0 \\
\hline Lineal distance (m) & 0 & 6 & 130 & 6 & 0 \\
\hline \multicolumn{6}{|l|}{ Running mater on trail } \\
\hline Occurrences (n) & 0 & 1 & 0 & 0 & 0 \\
\hline Lineal distance $(\mathrm{m})$ & 0 & 4 & 0 & 0 & 0 \\
\hline
\end{tabular}


Table 4 Summary of recreation site condition class and multi-indicator impact assessment system for case study protected areas in Costa Rica and Belize. NA = not available, $\mathrm{n}=$ number of occurrences.

\begin{tabular}{|c|c|c|c|c|}
\hline \multirow[t]{3}{*}{ Impact indicators } & \multicolumn{4}{|c|}{ Protected areas and locations affected } \\
\hline & \multirow{2}{*}{$\begin{array}{l}\text { Altun Ha- } \\
\text { archaeological site } \\
\text { Ruin plaza }\end{array}$} & \multicolumn{2}{|c|}{ Manuel Antonio National Park } & \multirow{2}{*}{$\begin{array}{l}\text { Volcan Poas National Park } \\
\text { Crater vieming area }\end{array}$} \\
\hline & & $\begin{array}{l}\text { Picnic area: } \\
\text { entrance }\end{array}$ & $\begin{array}{l}\text { Picnic area: } \\
\text { concessionaire }\end{array}$ & \\
\hline Condition class $(0-5)$ & 1 & 4 & 4 & NA \\
\hline Composition (100\%) & Vegetation & Bare soil & Bare soil & Gravelled \\
\hline Site size $\left(\mathrm{m}^{2}\right)$ & $2828020(283 \mathrm{ha})$ & 812 & 717 & 1129 \\
\hline Vegetation cover loss $(\%)$ & 10 & 91 & 91 & NA \\
\hline Exposed soil (\%) & 10 & 71 & 71 & NA \\
\hline Damaged trees (n) & 0 & 1 & 2 & 0 \\
\hline Exposed roots (n) & 0 & 0 & 0 & 0 \\
\hline Litter $(\%)$ & 0 & 0 & 5 & 0 \\
\hline
\end{tabular}

Recreation sites (and trails) in all the study areas were generally free of litter, with a small amount documented at the commercial picnic area in Manuel Antonio and in the ruin plaza at Altun $\mathrm{Ha}$. Other evidence of inappropriate human behaviour included graffiti and vandalism of ruin structures found at Altun Ha.

\section{Discussion}

\section{Visitor impacts and management conditions}

Visitor impacts at our study sites did not differ substantially from those reported in similar studies in the USA and elsewhere. Impacts to protected area resources were evident, particularly along trails. Common trail impacts included trail proliferation, erosion, widening, and exposed roots. We had expected to find more problems with muddiness along the trails located in tropical rain forests. However, most of these trails, such as those in Monteverde and Braulio Carrillo, had artificial surfacing to avoid or reduce tread muddiness.

Common recreation site impacts included vegetation and organic litter loss, and soil exposure. Water resource impacts included physical and biological pollution and wildlife impacts included the disturbance and feeding of animals. Other impacts included littering, artefact collection, graffiti and coral reef damage.

One principal difference was the absence of campsites and campsite impacts, which are more common in studies in the USA (Leung \& Marion 2000). Based on our observations and review of the regional travel literature, it is apparent that camping is a less popular recreation activity in Central American protected areas than elsewhere. Another difference was the absence of problems with recreation site expansion and proliferation, probably because the recreation sites that we evaluated had well-developed facilities and artificial borders that effectively concentrated visitor use.

Some unique management conditions influence visitor impact management within the protected areas of Belize and Costa Rica. Interview subjects identified severely limited budgeting and staffing as the most significant barrier to managing visitor impacts. Many protected areas in Central America have been labelled by ecotourism and conservation organizations as 'paper parks', which means there have been few or no management activities following legal designation. Resources to educate and regulate visitors, or to construct and maintain facilities, were described by interview subjects as insufficient to adequately protect natural resources. Our data and observations revealed higher levels of resource protection-related facilities and visitor management at the more highly visited (and funded) protected areas, like Monteverde and Volcan Poas, in comparison to the less visited areas, like Braulio Carrillo and the Community Baboon Sanctuary. The adequacy of these measures in protecting natural and cultural resources is difficult to objectively gauge, but in our judgment, resources were less protected at our study sites than at similar recreation settings in North American protected areas.

Competition for natural resources between local residents and protected area managers is another pertinent issue, sometimes resulting in poor relations between managers and local residents, and in conflicts with visitors. For example, if traditional land uses such as subsistence agriculture have been displaced to areas surrounding protected areas, local residents may engage in potentially harmful activities like slash and burn agriculture.

Another unique management condition is the confounding problem of shared natural resources between local residents and visitors. Some impacts, such as water pollution and trail proliferation, have been attributed to both visitors and local residents. Insufficient support from agency central office staff, inadequate infrastructure, tourist safety issues, poor distribution of tourist income between guides and protected area staff, and mismanagement of tourist fees represent other management challenges.

We found that knowledge of visitor impacts was generally minimal and that the central offices or their respective agencies had disseminated very little information on this topic. There have been studies conducted to determine carrying 
capacities and address other issues like zoning; however, these isolated examples have not been widely disseminated. Agencies have developed few policies and practices to guide managers in identifying, assessing or managing visitor impacts. This overall lack of awareness about visitor impacts was particularly evident regarding wildlife.

Minimizing visitor impacts to ecotourism attractions, such as howler monkeys, coral reefs and archaeological structures, is particularly critical to sustainable ecotourism. Managers frequently made impact management decisions without guidance from central offices, formal carrying capacity frameworks, or research and monitoring data. We also found that the visitor impact management actions that were taken emphasized manipulating resource conditions or visitor behaviour through regulations, rather than visitor education.

Interview subjects also said that it was important to promote and accommodate ecotourism visitation. Some government and tourism agencies and organizations may see promoting ecotourism visitation and minimizing visitation impacts as potentially conflicting goals. Any visitor management actions that reduced visitation would certainly be politically unpopular within the ecotourism industry. Belize may be in a good position to resolve such conflicts since a single governing branch, the Ministry of Tourism and the Environment, includes both tourism and the environment.

\section{Visitor impact management techniques}

Visitor impacts may be avoided or minimized through the proper location, construction, and maintenance of visitor sites and facilities or by managing visitor use through education or regulation (Cole et al. 1987; Leung \& Marion 2000). Interviews revealed that few of the study trails were professionally designed to minimize impact. In fact, most managers were not aware of the extensive literature on trail design, construction, and maintenance, in part due to a lack of Spanish translations. Our impact assessments subsequently revealed many visitor impacts that could have been avoided with improved location, design and construction practices (Hesselbarth \& Vachowski 1997; Birchard \& Proudman 2000). For example, trails at Braulio Carrillo, the Community Baboon Sanctuary and the Entrance trail at Manuel Antonio, were primarily composed of bare soil, had segments in wetter, less resistant areas, and lacked sufficient design and maintenance features for reinforcing treads or shielding them from impact. These trails thus experienced greater degradation, even though other trails that we investigated supported higher levels of traffic.

Locating trails and recreation sites in resistant or resilient areas can be an effective method for minimizing future visitor impact (Leung \& Marion 1996). For example, we observed little loss of vegetation cover in heavily used picnic areas at Volcan Poas or on the plaza of Altun Ha, where recreational trampling occurs only on mowed grassy vegetation. Conversely, we found extensive vegetation cover loss and exposed soil at the Manuel Antonio picnic areas, located in shady areas with fragile herbaceous ground cover. Similarly, trails aligned in sideslope settings on higher ground were narrower and less muddy and eroded than segments in flatter, lower terrain.

Our observations also revealed numerous innovative construction solutions to common recreation site and trail degradation problems. The Volcan Poas crater viewing area was fenced, gravelled, and had a large viewing deck to effectively concentrate use and prevent erosion and expansion of this heavily visited site. In Volcan Poas, Manuel Antonio and Monteverde, tread reinforcement and surfacing materials included use of embedded concrete lattice blocks, wood steps and cribbing filled with gravel, and cement walkways. Sections of the Braulio Carrillo trail were composed of crosssections of rot-resistant trees with flattened bottle caps or galvanized screen to improve traction. In particular, we highlight the extensive and highly effective application of concrete lattice blocks at Monteverde and other areas, which provide a porous, even tread with low steps and excellent traction. High rainfall, wet tropic soils, and shallow root systems make the use of such materials essential on most trails that receive moderate to heavy amounts of use.

Interviews and observations revealed varying levels and quality of trail maintenance work. Such work was effective when materials were locally available and staff had sufficient expertise. This was most evident at Monteverde and Volcan Poas, where active tread maintenance work was successful in directing surface water off trail treads and limiting expansion of trail widths and development of visitor-created trails. At the Baboon Sanctuary, limited staff and staff training requires a more creative approach to prevent trail degradation. Local residents who use some of these trails might be asked to help repair problem spots and tourist guides might be directed to ask visitors to remain on a core set of trails.

Our findings indicate that channelling use can reduce trail proliferation, but additional strategies may also be required. The installation of rope borders along the Entrance trail at Manuel Antonio was very effective in minimizing previous problems with trail proliferation. However, visitors accessing ruin buildings at Altun $\mathrm{Ha}$ have created numerous eroded access trails on the steep sides of the ruin structures. Managers have provided walkways with steps, but these access routes were not clearly marked nor were visitors specifically directed to stay on the formal trails. Some multilingual signs are needed. Given the irreplaceable nature of the ruin structures, the staff may also consider recruiting local volunteers to increase visitor contacts and providing resource protection training for the guides that accompany many of the visitor groups.

Use of visitor education and interpretation programmes can also be effective in reducing certain impacts by prescribing recommended low impact practices and behaviours (see URL http://www.LNT.org). All our study areas underused such programmes. The study areas also failed to use or effectively communicate regulations to visitors. With 
one exception (Hol Chan Marine Reserve), managers generally failed to communicate low impact practices or regulations to visitors or, indeed, provide a management presence. Interview subjects noted that staffing was insufficient to enforce regulations or that they lacked enforcement authority. All areas had a small visitor contact station or centre, but most lacked signs and other means to communicate low impact practices or regulations. None of the centres had information displays at the beginning of trails or distributed printed information such as pamphlets. A substantial future opportunity exists to more effectively communicate messages and regulations that will shape visitor behaviour in ways that avoid or reduce visitor impacts.

We note that promoting or requiring the use of guides can be an innovative and cost-effective method for reducing visitor impacts (Norris 1994; Marion \& Farrell 1998). In contrast to the USA and other developed countries, the use of guides is quite common at protected areas in Belize and Costa Rica. National guide licensing programmes exist in both countries, however, guides could be doing much more to teach and ensure that visitors use low-impact hiking and wildlifeviewing practices. Guides at Monteverde did instruct visitors in these practices and monitored compliance. However, we also witnessed guides encouraging and participating in certain undesirable behaviours, such as feeding howler monkeys so that visitors could obtain a closer view. In order for this strategy to be effective, guides must communicate and exemplify appropriate behaviours and low-impact practices.

\section{Utility of impact assessment techniques}

We applied and evaluated a variety of impact assessment techniques to determine which had greater management utility and were most feasible for developing-nation protected areas. We focused our selection of procedures on those that were efficient, yet yielded objective resource condition data. We did not employ time-consuming procedures that required permanently fixed points or extensive training. New rapid assessment procedures, like the trail condition class ratings, were developed to provide simpler options for documenting visitor impacts.

We found that most of the assessment procedures were applicable and generated useful information about trail and recreation site impacts. Condition class and rating systems were simple and quick to apply, generating basic information about a variety of soil and vegetation impacts. They are moderately to highly accurate and precise, although they only offer one piece of information about multiple impacts and have low sensitivity to change (Cole 1983). Categorical ratings can be more accurate and precise than condition class systems, are intermediate in sensitivity, but do not indicate the magnitude of change occurring within rating levels (Cole 1989). These systems are most useful for managers interested in rapid assessments of vegetation and soil conditions, particularly areas with limited budgets, staff and access to equipment (e.g. Braulio Carrillo or Altun Ha). However, these procedures were not applicable on sites and trails with artificial surfacing (e.g. gravel) like those found at Volcan Poas and Monteverde.

We successfully applied measurement-based systems to all of the study areas and generated more comprehensive and quantitative information of higher management utility. Greater emphasis on detailed monitoring protocols and training generally yields data with higher levels of precision and accuracy (Cole 1989). The methods employed can address a wide variety of site and trail impacts, permitting quantitative summaries and statistical analyses to determine the extent and magnitude of impacts. In this study, trail point sampling permitted basic comparison of the average and range of trail width and incision on multiple trails. We can also compare impacts on trails and sites of differing compositions, to demonstrate the effectiveness of construction and maintenance activities. Trail problem assessment procedures identified the number and location of impact occurrences, their lineal extent, and the percentage of the trail affected by six impact indicators. This information can be used to determine the proportion of trails affected by specific impacts and direct trail maintenance crews to repair specific problem spots.

One drawback of measurement-based systems for the protected areas that we evaluated is their more sophisticated and time-intensive measurement procedures. For example, recreation site size determinations using the geometric figure method required selection of the most appropriate shape(s), and determination of which dimensions needed to be measured. This may limit their use to parks with larger budgets and staff, such as Monteverde, Manuel Antonio and Volcan Poas in our study.

In selecting a preferred monitoring method, managers must begin by specifying their monitoring objectives, define impacts of particular importance, and evaluate the merits of alternative approaches. Such evaluations require consideration of trade-offs in measurement time, validity and reliability. For example, in this study, the condition class and ratings methods provided rapid characterizations of general resource conditions but were incapable of tracking subtle changes in specific trail or recreation site conditions. Conversely, the more intensive measurement-based methods yielded multiple measures for a variety of indicators that permitted greater sensitivity and flexibility in monitoring changes in resource conditions.

The alternative visitor impact monitoring methods developed and evaluated in this study can be applied with limited modifications to a wide variety of settings. Condition class descriptions can be developed for any combination of resource conditions. Definitions and photographs that describe trail or recreation site boundaries can be developed for different and unique environmental settings. For trails, the point sampling method is more universal and requires fewer modifications than the problem assessment method. The latter would require adaptations to different environments that may limit the comparability of data. 
Our experience training protected area staff in North, Central and South America has shown that comprehensive procedural manuals and field training can make implementation of impact assessment and monitoring programs feasible for most protected areas. Impact monitoring workshops for Latin American protected area managers have been provided by the National Outdoor Leadership School, Colorado State University, and The Mountain Institute. Once procedures are developed and staff are trained, most systems require little time to apply and can be incorporated into existing staff duties. Furthermore, visitor impact monitoring is typically conducted at longer intervals, such as every $3-5$ years. Partnerships with local guides and volunteers, regional universities, or NGOs provide alternative opportunities to accomplish such work.

Protected area managers identified wildlife, water resource, attraction feature and other impacts as other issues of concern, indicating that assessment procedures are needed to assess these impacts as well.

\section{Conclusion}

This study characterized visitor impacts occurring in eight protected areas using data from interviews and trail and recreation site condition assessments, and applied and compared alternative rapid assessment procedures to explore their management utility.

It is not possible to extend general conclusions about our study findings beyond the case study sites, since we did not randomly sample protected areas, trails and sites. However, the protected areas selected for this study represented a wide range of attributes and characteristics, reflecting a larger diversity of protected areas in these two countries. Additionally, we selected trails and recreation sites to reflect natural resource conditions most directly related to visitor use, to avoid confounding results from local use and to ensure that we measured areas where intensive visitor use was occurring.

The most important study findings are that (1) a variety of visitor use-related resource impacts are occurring, similar to those found in the USA, (2) a number of management techniques are available to minimize these impacts, (3) there are a range of rapid assessment techniques for documenting both impacts and the effectiveness of management interventions, and (4) it is possible to reduce barriers to monitoring, such as limited funding and staffing.

\section{Acknowledgements}

The authors would like to acknowledge and thank the following individuals for reviewing early drafts of this paper: Troy Hall, Bruce Hull, Muzaffer Uysal, Jim Fraser, and YuFai Leung. We would also like to thank the interview subjects for their participation in and valuable input to this study.

\section{References}

Alderman, C.L. (1990) A study of the role of privately owned lands used for nature tourism, education and conservation. Unpublished report, Conservation International, Washington, DC, USA: 66 pp.

Back, M. \& Barry, O. (1996) Costa Rica. In: Central America, 2nd edition, ed. A.D. Nystrom \& W. Smith, pp. 359-444. New York, USA: Fodor's Travel Publications, Inc.

Backman, K.F. \& Potts, T.D. (1993) Profiling nature-based travelers: southeastern market segments. Unpublished report, Strom Thurmond Institute, Clemson, SC, USA.

Birchard, W. \& Proudman, R.D. (2000) Appalachian Trail Design, Construction, and Maintenance,. 2nd edition. Harpers Ferry, WV, USA: Appalachian Trail Conference: 237 pp.

Boo, E. (1990) Ecotourism: The Potentials and Pitfalls, Volume 1. Washington, DC, USA: World Wildlife Fund: 165 pp.

Boucher, D.H., Aviles, J., Chepote, R., Dominguez-Gil, O.E. \& Vilchez, B. (1991) Recovery of trailside vegetation from trampling in a tropical rainforest. Environmental Management 15: 257-262.

Cole, D.N. (1983) Monitoring the condition of wilderness campsites. Research Paper INT-302, US Department of Agriculture, Forest Service, Intermountain Forest and Range Experiment Station, Ogden, UT, USA: 10 pp.

Cole, D.N. (1989) Wilderness campsite monitoring methods: a sourcebook. General Technical Report INT-259, US Department of Agriculture, Forest Service, Intermountain Research Station, Ogden, UT, USA: 57 pp.

Cole, D.N., Petersen, M.E. \& Lucas, R.C. (1987) Managing wilderness recreation use: common problems and potential solutions. General Technical Report INT-230, US Department of Agriculture, Forest Service, Intermountain Research Station, Ogden, UT, USA: $60 \mathrm{pp}$.

Epler-Wood, M. (1998) Meeting the global challenge of community participation in ecotourism: case studies and lessons from Ecuador. Working Paper No. 2, The Nature Conservancy, Arlington, VA, USA: 32 pp.

Giongo, F., Bosco-Nizeye, J. \& Wallace, G.N. (1994) A study of visitor management in the world's national parks and protected areas. Unpublished report, College of Natural Resources, Colorado State University, The Ecotourism Society, and International Union for the Conservation of Nature. Fort Collins, CO, USA: 137 pp.

Hesselbarth, W. \& Vachowski, B. (1996) Trail construction and maintenance notebook. 9623-2833-MTDC, USDA Forest Service, Technology and Development Program, Missoula, MT, USA: 139 pp.

Hunter, C. \& Green, H. (1995) Tourism and the Environment: A Sustainable Relationship? London, UK: Routledge.

ICT-Costa Rica Tourist Board (1998) Naturally Costa Rica: The visitor guide to Costa Rica. Costa Rican National Chamber of Tourism, the Costa Rica Tourist Board and the Costa Rican Investment and Development Board, San Jose, Costa Rica: 98 pp.

Jacobson, S.K. \& Lopez, A.F. (1994) Biological impacts of ecotourism: tourists and nesting turtles in Tortuguero National Park, Costa Rica. Wildlife Society Bulletin 22: 414-419.

Leung, Y.-F. \& Marion, J.L. (1996) Trail degradation as influenced by environmental factors: a state of the knowledge review. Fournal of Soil and Water Conservation 51: 130-136.

Leung, Y.-F. \& Marion, J.L. (1999a) The influence of sampling 
interval on the accuracy of trail impact assessment. Landscape and Urban Planning 43: 167-179.

Leung, Y.-F. \& Marion, J.L. (1999b) Assessing trail conditions in protected areas: Application of a problem-assessment method in Great Smoky Mountains National Park. Environmental Conservation 26: 270-279.

Leung, Y.-F., Marion, J.L. \& Ferguson, J.Y. (1997) Methods for assessing and monitoring backcountry trail conditions: an empirical comparison. In: Making Protection Work: Proceedings of the 9th Conference on Research and Resource Management in Parks and on Public Lands, The 1997 George Wright Society Biennial Conference, ed. D. Harmon, pp. 406-414. Hancock, Michigan, USA: The George Wright Society.

Leung, Y.-F. \& Marion, J.L. (2000) Recreation impacts and management in wilderness: a state-of-knowledge review. In: Proceedings: Wilderness Science in the Time of Change, 23-27 May 1999, Missoula, MT, USA, Proceedings RMRS-P-15-Vol-5, ed. D.N. Cole \& S. F. McCool, pp. 23-48. Ogden, UT, USA: US Department of Agriculture, Forest Service, Rocky Mountain Research Station.

Mahler, R. \& Wotkyns, S. (1997) Belize: Adventures in Nature. Santa Fe, NM, USA: John Muir Publications.

Marion, J.L. (1991) Developing a natural resource inventory and monitoring program for visitor impacts on recreation sites: A procedural manual. NPS/NRVT/NRR91/06, US Department of the Interior, National Park Service, Denver Service Center, Denver, CO, USA: 59 pp.

Marion, J.L. (1995) Capabilities and management utility of recreation impact monitoring programs. Environmental Management 19: 763-771.

Marion, J.L. \& Farrell, T.A. (1998) Managing ecotourism visitation in protected areas. In: Ecotourism Planning and Management, ed. K. Lindberg \& D. Englestrom, pp. 155-182. North Bennington, VT, USA: The Ecotourism Society: 244 pp.

Marion, J.L. \& Leung, Y.-F. (1998) International recreation ecology research and ecotourism management. In: Wildland Recreation: Ecology and Management, ed. W.E. Hammitt \& D.N. Cole, pp. 328-346. New York, USA: John Wiley \& Sons, Inc.

Mieczkowski, Z. (1995) Environmental Issues of Tourism and Recreation. Lanham, MD, USA: University Press of America: $552 \mathrm{pp.}$

Norris, R. (1994) Ecotourism in the National Parks of Latin America. National Parks. 68: 33-37.

Wallin, T.R. \& Harden, C.P. (1996) Estimating trail-related soil erosion in the humid tropics: Jatun Sacha, Ecuador, and La Selva, Costa Rica. Ambio 25: 517-522.

WCED (1987) Our Common Future. Report of the World Commission on Environment and Development, The Brundtland Commission. Oxford, UK: Oxford University Press: 398 pp.

Wight, P.A. (1996) North American ecotourism markets: Motivations, preferences and destinations. Fournal of Travel Research 35: 3-9. 